\title{
Luminescent metal complexes derived from carbene and related ligands: tuning excited-state properties with metal-carbon multiple bonds
}

\author{
Siu-Wai Lai ${ }^{a}$, Michael C.W. Chan ${ }^{a}$, Yue Wang ${ }^{a}$, Hiu-Wah Lam ${ }^{\text {a }}$, Shie-Ming Peng ${ }^{b}$, \\ Chi-Ming Che ${ }^{a, *}$ \\ a Department of Chemistry, The University of Hong Kong, Pokfulam Road, Hong Kong, PR China \\ b Department of Chemistry, National Taiwan University, Taipei, Taiwan
}

Received 11 August 2000; accepted 4 October 2000

\begin{abstract}
This account begins with a report on the photophysical responses to $\mathrm{pH}$ exhibited by the luminescent chelating bis(carbene) platinum(II) complexes $\left[\left(\mathrm{C}_{10} \mathrm{H}_{21} \mathrm{~N}_{4}\right) \mathrm{Pt}(\mathrm{CN})\left(\mathrm{CN}^{t} \mathrm{Bu}\right)\right](\mathbf{1})$ and $\left[\left(\mathrm{C}_{10} \mathrm{H}_{21} \mathrm{~N}_{4}\right) \mathrm{Pt}\left(\mathrm{CN}^{t} \mathrm{Bu}\right)_{2}\right]^{+}$(2), and concludes with an overview of recent work by our group regarding luminescent platinum and rhenium derivatives bearing metal-carbon multiple bonds. (C) 2001 Elsevier Science B.V. All rights reserved.
\end{abstract}

Keywords: Carbene; Photoluminescence; Platinum; Protonation; Rhenium; Sensors

\section{Introduction}

As research into the preparation of metal carbene complexes and their roles as stoichiometric and catalytic reagents have proliferated [1], their luminescent characteristics have largely been neglected. Yet such investigations are potentially rewarding, because the population of charge-transfer excited states can transform the nature and reactivity of the metal-carbene moiety. By analogy to the rich photochemistry displayed by $\mathrm{d}^{2}$ derivatives containing metal-ligand multiple bonds [2,3], the metal-carbene interaction may be weakened or modified in the excited state to yield species capable of mediating photo-induced electron transfer or carbene group transfer reactions.

The photochemistry of the Group 6 Fischer carbene complexes $\left[(\mathrm{CO})_{5} \mathrm{M}=\mathrm{C}(\mathrm{OR}) \mathrm{R}^{\prime}\right](\mathrm{M}=\mathrm{Cr}, \mathrm{W})$ have been studied in some detail [4] and applications in organic

\footnotetext{
* Corresponding author. Tel.: +852-28592154; fax: +85228571586.

E-mail address: cmche@hku.hk (C.-M. Che).
}

synthesis have been developed [5]. Yam et al. have described the luminescent behavior of ruthenium(II) bipyridine complexes with orthometalated aminocarbene moieties [6]. The first observation of a metal $\rightarrow$ $\pi^{*}$ (carbene) charge transfer excited state in solution at ambient temperatures was reported by our group for the hexanuclear platinum(II) macrocycle $[\mathrm{Pt}(\mathrm{CN})$ $\left.\left(\mathrm{C}_{10} \mathrm{H}_{21} \mathrm{~N}_{4}\right)\right]_{6}$ bearing chelating bis(carbene) and bridging cyanide ligands [7]. Our endeavors in developing luminescent metal-carbon multiple-bonded species have also proved fruitful for low-valent Pt(II) [8] and $\operatorname{Re}(\mathrm{I})$ [9] carbene derivatives supported by diimine auxiliaries, while the preparation and excited-state properties of high-valent $\operatorname{Re}(\mathrm{V})$ [10,11] and -(VI) [12] alkylidyne luminophores have been undertaken; an overview of this body of work is given at the end of this account. Mayr et al. [13] first noted fluid luminescence from alkylidyne complexes in 1985, but reports of further examples remain sparse $[14,15]$.

The new study which constitutes the main focus of this account was inspired by early reports that protonation of chelating bis(carbene) platinum(II) complexes 
such as $\left[\left(\mathrm{C}_{4} \mathrm{H}_{9} \mathrm{~N}_{4}\right) \mathrm{Pt}\left(\mathrm{CNCH}_{3}\right)_{2}\right]^{+}$occurred at the heterocyclic bis(carbene) moiety [16]. We perceived these species as potential $\mathrm{pH}$ sensors because the reaction was reversible upon treatment with base and the protonation was accompanied by a color change from red to yellow. In addition, their photoluminescent properties are hitherto unknown. Significantly, a number of Pt(II) complexes have been identified as prospective luminescent chemical sensors [17]. Compared to luminescent octahedral $d^{6}$ metal species, square planar $d^{8} \operatorname{Pt}($ II) derivatives can offer superior chemical sensing capabilities because the coordinatively unsaturated geometry facilitates outer- and inner-sphere interactions with substrates. We now described the synthesis and spectroscopic properties of the chelating bis(carbene) $\mathrm{Pt}(\mathrm{II})$ analogs $\left[\left(\mathrm{C}_{10} \mathrm{H}_{21} \mathrm{~N}_{4}\right) \mathrm{Pt}(\mathrm{CN})\left(\mathrm{CN}^{t} \mathrm{Bu}\right)\right] \quad$ (1) and $\left[\left(\mathrm{C}_{10} \mathrm{H}_{21} \mathrm{~N}_{4}\right) \mathrm{Pt}\left(\mathrm{CN}^{t} \mathrm{Bu}\right)_{2}\right]^{+}$(2), together with the crystal structure of 1 . Their photophysical responses upon treatment with tetrafluoroboric acid, and in particular observations of photoluminescent enhancement, are also presented. Kaiwar et al. have recently examined the impact of protonation upon the excited-state parameters of heterocycle-substituted platinum-1,2enedithiolate complexes [18].

\section{Experimental}

\subsection{General procedures}

$\mathrm{K}_{2} \mathrm{PtCl}_{4}$ (Strem), tert-butylisocyanide (Aldrich) and hydrazine hydrate (Aldrich) were used as received. (Caution: perchlorate salts are potentially explosive and should be handled with care and in small amounts.) Solvents used for synthesis were of analytical grade and purified according to conventional methods. Fast atom bombardment (FAB) mass spectra were obtained on a Finnigan Mat 95 mass spectrometer. ${ }^{1} \mathrm{H}(300 \mathrm{MHz})$ and ${ }^{13} \mathrm{C}(126 \mathrm{MHz})$ spectra were recorded on DPX 300 and 500 Bruker FT-NMR spectrometers, respectively, with chemical shift (in $\mathrm{ppm}$ ) relative to tetramethylsilane. Elemental analysis was performed by the Institute of Chemistry at the Chinese Academy of Sciences, Beijing. Infrared (IR) spectra were recorded as Nujol mulls on a BIO RAD FTIR spectrometer. UV-vis absorption spectra were recorded on a Perkin-Elmer Lambda 19 $\mathrm{UV}$-vis spectrophotometer.

Steady-state emission spectra were recorded on a SPEX 1681 Fluorolog-2 series F111AI spectrophotometer. Low-temperature $(77 \mathrm{~K})$ emission spectra for solidstate samples were recorded in 5-mm diameter quartz tubes which were placed in a liquid nitrogen Dewar equipped with quartz windows. The emission spectra were corrected for monochromator and photomultiplier efficiency and for xenon lamp stability.
Sample and standard solutions were degassed with at least three freeze-pump-thaw cycles. The emission quantum yield was measured with $\left[\mathrm{Ru}(\mathrm{bpy})_{3}\right]\left(\mathrm{PF}_{6}\right)_{2}$ in degassed acetonitrile as the standard $\left(\Phi_{\mathrm{r}}=0.062\right)$ and calculated by: $\Phi_{\mathrm{s}}=\Phi_{\mathrm{r}}\left(B_{\mathrm{r}} / B_{\mathrm{s}}\right)\left(n_{\mathrm{s}} / n_{\mathrm{r}}\right)^{2}\left(D_{\mathrm{s}} / D_{\mathrm{r}}\right)$, where the subscripts $\mathrm{s}$ and $\mathrm{r}$ refer to sample and reference standard solution, respectively, $n$ is the refractive index of the solvents, $D$ is the integrated intensity, and $\Phi$ is the luminescence quantum yield. The quantity $B$ is calculated by: $B=1-10^{-A L}$; where $A$ is the absorbance at the excitation wavelength and $L$ is the optical path length.

Emission lifetimes and flash-photolysis measurements were performed with a Quanta Ray DCR-3 pulsed $\mathrm{Nd}$ :YAG laser system (pulse output $355 \mathrm{~nm}, 8 \mathrm{~ns}$ ). The emission signals were detected by a Hamamatsu R928 photomultiplier tube and recorded on a Tektronix model 2430 digital oscilloscope. Error limits are estimated for: $\lambda( \pm 1 \mathrm{~nm}), \tau( \pm 10 \%), \phi( \pm 10 \%)$.

\subsection{Syntheses}

\subsection{1. $\left[\left(\mathrm{C}_{10} \mathrm{H}_{21} \mathrm{~N}_{4}\right) \mathrm{Pt}(\mathrm{CN})\left(\mathrm{CN}^{t} \mathrm{Bu}\right)\right]$ (1) and \\ $\left.\left[\left(\mathrm{C}_{10} \mathrm{H}_{21} \mathrm{~N}_{4}\right) \mathrm{Pt}_{(\mathrm{CN}} \mathrm{Bu}\right)_{2}\right] \mathrm{ClO}_{4}\left(2\left(\mathrm{ClO}_{4}\right)\right)$}

To a stirred solution of $\mathrm{K}_{2} \mathrm{PtCl}_{4}(0.20 \mathrm{~g}, 0.48 \mathrm{mmol})$ in $\mathrm{H}_{2} \mathrm{O}(20 \mathrm{ml})$ at room temperature was added tertbutylisocyanide, ${ }^{t} \mathrm{BuN} \equiv \mathrm{C}(0.20 \mathrm{~g}, 2.41 \mathrm{mmol})$. A colorless solution of the $\left[\mathrm{Pt}\left(\mathrm{CN}^{t} \mathrm{Bu}\right)_{4}\right]^{2+}$ cation was formed. An excess of hydrazine hydrate $(1 \mathrm{ml})$ was added to give a yellow solution, which was stirred at $40^{\circ} \mathrm{C}$ for 2 $\mathrm{h}$. The resultant yellow precipitation was collected, washed with water and dried to yield complex $\mathbf{1}$ as a yellow solid: yield $0.04 \mathrm{~g}, 15 \%$. To the yellow filtrate was added excess $\mathrm{LiClO}_{4}$ to yield $\mathbf{2}\left(\mathrm{ClO}_{4}\right)$ as a yellow solid: yield $0.20 \mathrm{~g}, 63 \%$. Recrystallization of $\mathbf{1}$ and $2\left(\mathrm{ClO}_{4}\right)$ by diffusion of diethyl ether into chloroform solutions yielded yellow crystals.

2.2.1.1. Compound 1. Anal. Calc. for $\mathrm{C}_{16} \mathrm{H}_{30} \mathrm{~N}_{6} \mathrm{Pt}$ : C, 38.32; H, 6.03; N, 16.76. Found: C, 38.22; H, 5.98; N, 16.87\%. FAB-MS: $m / z 502\left[\mathrm{M}^{+}\right], 445\left[\mathrm{M}^{+}{ }^{-} \mathrm{Bu}\right]$. IR (Nujol): $v=2197,2132(\mathrm{C} \equiv \mathrm{N}), 1562,1534(\mathrm{C}=\mathrm{N}) \mathrm{cm}^{-1}$. ${ }^{1} \mathrm{H}-\mathrm{NMR} \quad\left(\mathrm{CDCl}_{3}\right)$ : 1.37, 1.41 (two singlets, $18 \mathrm{H}$, $\left.{ }^{t} \mathrm{BuNH}\right), 1.59$ (s, 9H, $\left.{ }^{t} \mathrm{BuNC}\right), 4.17$ (broad s, $\left.1 \mathrm{H}, \mathrm{NH}\right)$, 6.55 (broad s, 1H, NH), 8.11 (broad s, 1H, NH). ${ }^{13} \mathrm{C}\left\{{ }^{1} \mathrm{H}\right\}$-NMR $\left(\mathrm{CD}_{3} \mathrm{CN}\right): 28.1,28.2,29.1\left(\mathrm{CMe}_{3}\right), 52.6$, 52.7, $52.9\left(\mathrm{CMe}_{3}\right)$; remaining signals not resolved.

2.2.1.2. Compound 2(ClO $)_{4}$. Anal. Calc. for $\mathrm{C}_{20} \mathrm{H}_{39} \mathrm{~N}_{6}$ $\mathrm{ClO}_{4} \mathrm{Pt}: \mathrm{C}, 36.50 ; \mathrm{H}, 5.97$; N, 12.77. Found: $\mathrm{C}, 36.45$; $\mathrm{H}, 5.81 ; \mathrm{N}, 12.86 \%$. FAB-MS: $m / z 558\left[\mathrm{M}^{+}\right], 502$ $\left[M^{+}-{ }^{t} \mathrm{Bu}\right]$. IR (Nujol): $v=2229,2206(\mathrm{C} \equiv \mathrm{N}), 1571$, $1531(\mathrm{C}=\mathrm{N}) \mathrm{cm}^{-1} \cdot{ }^{1} \mathrm{H}-\mathrm{NMR}\left(\mathrm{CD}_{3} \mathrm{CN}\right): 1.37(\mathrm{~s}, 18 \mathrm{H}$, $\left.{ }^{t} \mathrm{BuNH}\right), 1.58$ (s, $\left.18 \mathrm{H},{ }^{t} \mathrm{BuNC}\right), 4.92($ broad s, $2 \mathrm{H}, \mathrm{NH})$, 8.69 (broad s, $1 \mathrm{H}, \mathrm{NH}) .{ }^{13} \mathrm{C}\left\{{ }^{1} \mathrm{H}\right\}-\mathrm{NMR}\left(\mathrm{CD}_{3} \mathrm{CN}\right): 28.9$, $29.9\left(\mathrm{CMe}_{3}\right), 54.5,61.0\left(\mathrm{CMe}_{3}\right)$; remaining signals not resolved. 
2.2.2. $\left[\left(C_{10} H_{22} N_{4}\right) \operatorname{Pt}(C N)\left(C N^{t} B u\right)\right] B F_{4}\left(3\left(B F_{4}\right)\right)$ and $\left.\left(\mathrm{C}_{10} \mathrm{H}_{22} \mathrm{~N}_{4}\right) \mathrm{Pt}\left(\mathrm{CN}^{t} \mathrm{Bu}\right)_{2}\right]\left(\mathrm{BF}_{4}\right)_{2}\left(\mathbf{4}\left(\mathrm{BF}_{4}\right)_{2}\right)$

$\mathrm{HBF}_{4}(50 \%)$ was added dropwise to an acetonitrile solution $(15 \mathrm{ml})$ of $1(0.10 \mathrm{~g}, 0.20 \mathrm{mmol})$ until a colorless solution was afforded. The solvent volume was reduced and addition of diethyl ether gave a white solid. This was collected, dried, and recrystallized by slow diffusion of diethyl ether into an acetonitrile solution to yield white crystals of $3\left(\mathrm{BF}_{4}\right)$. This procedure was adopted using $2\left(\mathrm{ClO}_{4}\right)(0.10 \mathrm{~g}, 0.15 \mathrm{mmol})$ to afford $\mathbf{4}\left(\mathrm{BF}_{4}\right)_{2}$.

2.2.2.1. Compound 3(BF $)$. Yield $0.09 \mathrm{~g}, 75 \%$. Anal. Calc. for $\mathrm{C}_{16} \mathrm{H}_{31} \mathrm{~N}_{6} \mathrm{BF}_{4} \mathrm{Pt}$ : C, 32.61; H, 5.30; N, 14.26. Found: C, 32.80; H, 5.01; N, 14.19\%. FAB-MS: $m / z$ $503\left[\mathrm{M}^{+}\right], 446\left[\mathrm{M}^{+}{ }^{t} \mathrm{Bu}\right]$. IR (Nujol): $v=2223,2140$ $(\mathrm{C} \equiv \mathrm{N}), 1567,1529(\mathrm{C}=\mathrm{N}) \mathrm{cm}^{-1} \cdot{ }^{1} \mathrm{H}-\mathrm{NMR}\left(\mathrm{CDCl}_{3}\right)$ : 1.46, 1.47 (two singlets, $18 \mathrm{H},{ }^{t} B u \mathrm{NH}$ ), $1.66(\mathrm{~s}, 9 \mathrm{H}$, ${ }^{t} \mathrm{BuNC}$ ), 5.70 (s with ${ }^{195} \mathrm{Pt}$ satellites, $1 \mathrm{H},{ }^{3} \mathrm{~J}_{\mathrm{PtH}}=26.4$ $\mathrm{Hz},{ }^{t} \mathrm{BuNH}$ ), 7.18 (s with ${ }^{195} \mathrm{Pt}$ satellites, $1 \mathrm{H},{ }^{3} J_{\mathrm{PtH}}=$ $33.5 \mathrm{~Hz},{ }^{t} \mathrm{BuNH}$ ), 9.92, 9.99 (two singlets with overlapping ${ }^{195} \mathrm{Pt}$ satellites, $2 \mathrm{H},{ }^{3} J_{\mathrm{PtH}}=67.5$ and $71.5 \mathrm{~Hz}$, heterocyclic $\mathrm{NH}) .{ }^{13} \mathrm{C}\left\{{ }^{1} \mathrm{H}\right\}-\mathrm{NMR}\left(\mathrm{CD}_{3} \mathrm{CN}\right): 27.1,28.5$ $\left(\mathrm{CMe}_{3}\right), 55.0,55.4\left(\mathrm{CMe}_{3}\right)$; remaining signals not resolved.

2.2.2.2. Compound $4\left(\mathrm{BF}_{4}\right)_{2}$. Yield $0.08 \mathrm{~g}, 70 \%$. Anal. Calc. for $\mathrm{C}_{20} \mathrm{H}_{40} \mathrm{~N}_{6} \mathrm{~B}_{2} \mathrm{~F}_{8} \mathrm{Pt}$ : C, 32.76; H, 5.50; N, 11.46. Found: C, 32.84; H, 5.46; N, 11.28\%. FAB-MS: $m / z$ $559\left[\mathrm{M}^{+}\right], 502\left[\mathrm{M}^{+}{ }_{-}{ }^{t} \mathrm{Bu}\right]$. IR (Nujol): $v=2230(\mathrm{C} \equiv \mathrm{N})$, 1597, $1571(\mathrm{C}=\mathrm{N}) \mathrm{cm}^{-1} .{ }^{1} \mathrm{H}-\mathrm{NMR}\left(\mathrm{CD}_{3} \mathrm{CN}\right): 1.45(\mathrm{~s}$, $\left.18 \mathrm{H},{ }^{t} \mathrm{Bu} \mathrm{NH}\right), 1.62\left(\mathrm{~s}, 18 \mathrm{H},{ }^{t} \mathrm{BuNC}\right), 6.43$ (broad s, $2 \mathrm{H}$, ${ }^{3} J_{\mathrm{PtH}}=26.4 \mathrm{~Hz},{ }^{t} \mathrm{BuNH}$ ), 9.61 (s with ${ }^{195} \mathrm{Pt}$ satellites,<smiles>CC(C)(C)N=C1NN=C(NC(C)(C)C)P1(C)(C#N)C(C)(C)C</smiles>
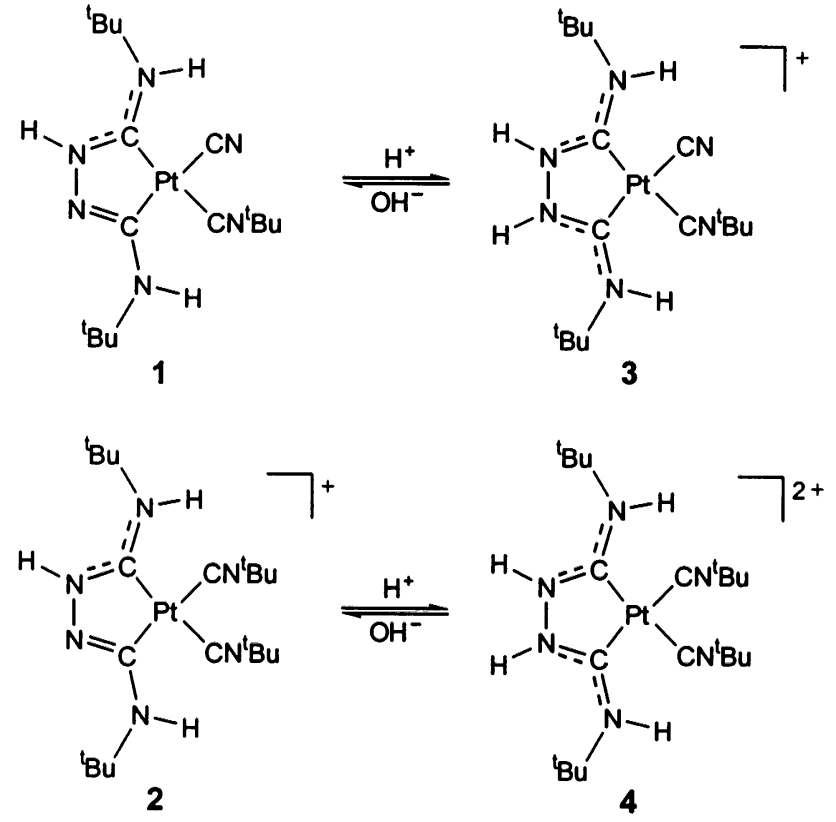

Fig. 1. Interconversion between $\mathbf{1} / \mathbf{3}$ and $\mathbf{2} / \mathbf{4}$.
$2 \mathrm{H},{ }^{3} J_{\mathrm{PtH}}=63.8 \mathrm{~Hz}$, heterocyclic $\left.\mathrm{NH}\right) .{ }^{13} \mathrm{C}\left\{{ }^{1} \mathrm{H}\right\}-\mathrm{NMR}$ (DMSO-d $\left.)_{6}\right)$ :28.1, $28.9\left(\mathrm{CMe}_{3}\right), 53.1,59.4\left(\mathrm{CMe}_{3}\right)$; remaining signals not resolved.

\subsection{Procedure for examining effects of $\mathrm{pH}$ on photophysical properties}

A solution of $2\left(\mathrm{ClO}_{4}\right)$ was prepared by dissolving the complex $(7.17 \mathrm{mg}, 0.01 \mathrm{mmol})$ in aqueous $\mathrm{NaCl}$ solution $(0.1 \mathrm{M}, 50 \mathrm{ml})$. The $\mathrm{pH}$ of the solution was adjusted by addition of aqueous $\mathrm{HBF}_{4}\left(3 \times 10^{-2} \mathrm{M}\right)$. The $\mathrm{pH}$ value was monitored with a $\mathrm{pH}$ meter and the absorption spectra at various $\mathrm{pH}$ values were recorded.

\subsection{X-ray crystallography}

Yellow crystals of $\left[\left(\mathrm{C}_{10} \mathrm{H}_{21} \mathrm{~N}_{4}\right) \mathrm{Pt}(\mathrm{CN})\left(\mathrm{CN}^{t} \mathrm{Bu}\right)\right]$ (1) were obtained by vapor diffusion of diethyl ether into a chloroform solution. Crystal data: $\mathrm{C}_{16} \mathrm{H}_{30} \mathrm{~N}_{6} \mathrm{Pt}, M=$ 501.53, crystal size $=0.40 \times 0.30 \times 0.26 \mathrm{~mm}$, orthorhombic, $\quad P 22_{1} 2_{1} 2_{1}, \quad a=9.392(2), \quad b=12.925(2)$, $c=17.211(2) \AA, V=2089.4(6) \AA^{3}, Z=4, D_{\text {calc }}=1.594$ $\mathrm{g} \mathrm{cm}^{-3}, \mu=6.723 \mathrm{~mm}^{-1}, F(000)=984, T=295 \mathrm{~K}$. A total of 2712 independent reflections were collected on a Nonius CAD4 diffractometer $\left(\lambda\left(\mathrm{Mo}_{-} \mathrm{K}_{\alpha}\right)=0.71073\right.$ $\AA, \theta$ range $=1.97-27.50^{\circ}$ ). The structure was solved by direct methods and refined by full-matrix least-squares treatment on $F^{2}$ using SHELXTL [19]. All $\mathrm{H}$ atoms were generated in idealized positions and refined in riding model together with attached atoms (the atoms $\mathrm{H}(3)$ and $\mathrm{H}(4)$ each have occupation numbers of 0.5 since $\mathrm{C}(7)-\mathrm{N}(3), \mathrm{C}(8)-\mathrm{N}(4)$ and $\mathrm{C}(7)-\mathrm{N}(5), \mathrm{C}(8)-\mathrm{N}(6)$ are indistinguishable): $R=0.029, w R=0.061, \mathrm{GoF}=1.035$ for 2281 absorption-corrected (semi-empirical from $\phi$ scans, transmission $0.161-0.253$ ) reflections with $I>$ $2 \sigma(I)$ and 209 parameters (residual $\rho=+1.59,0.66 \mathrm{e}$ $\left.\AA^{-3}\right)$.

\section{Results and discussion}

\subsection{Synthesis and characterization of mononuclear platinum(II) chelating bis(carbene) complexes}

The synthesis of mononuclear platinum(II) complexes with a heterocyclic monoanionic planar bis(carbene) ligand by treating a concentrated aqueous solution of $\mathrm{K}_{2} \mathrm{PtCl}_{4}$ with alkyl isocyanide then hydrazine has long been known [16a]. In this work, reaction of $\mathrm{K}_{2} \mathrm{PtCl}_{4},{ }^{t} \mathrm{BuNC}$ and hydrazine in $\mathrm{H}_{2} \mathrm{O}$ at $40^{\circ} \mathrm{C}$ resulted in the precipitation of $\left[\left(\mathrm{C}_{10} \mathrm{H}_{21} \mathrm{~N}_{4}\right) \mathrm{Pt}(\mathrm{CN})\right.$ $\left.\left(\mathrm{CN}^{t} \mathrm{Bu}\right)\right]$ (1) in low yield $(15 \%)$. Addition of excess $\mathrm{LiClO}_{4}$ to the filtrate afforded $\left[\left(\mathrm{C}_{10} \mathrm{H}_{21} \mathrm{~N}_{4}\right) \mathrm{Pt}\left(\mathrm{CN}^{t} \mathrm{Bu}\right)_{2}\right]-$ $\mathrm{ClO}_{4}\left(2\left(\mathrm{ClO}_{4}\right)\right)$ as a yellow solid in $63 \%$ yield. Protonation of 1 and $2\left(\mathrm{ClO}_{4}\right)$ with aqueous $\mathrm{HBF}_{4}$ solution gave $\left[\left(\mathrm{C}_{10} \mathrm{H}_{22} \mathrm{~N}_{4}\right) \mathrm{Pt}(\mathrm{CN})\left(\mathrm{CN}^{t} \mathrm{Bu}\right)\right] \mathrm{BF}_{4} \quad\left(3\left(\mathrm{BF}_{4}\right)\right)$ and 


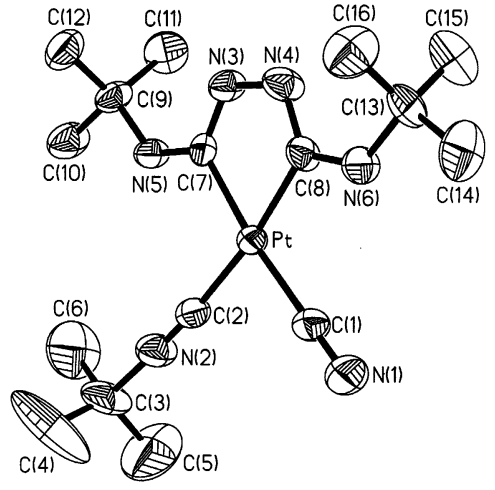

Fig. 2. Perspective view of $\mathbf{1}$ ( $50 \%$ probability ellipsoids).

Table 1

Selected bond lengths $(\AA)$ and angles $\left({ }^{\circ}\right)$ for $\mathbf{1}$

\begin{tabular}{lcll}
\hline $\mathrm{Pt}-\mathrm{C}(1)$ & $2.006(8)$ & $\mathrm{C}(7)-\mathrm{N}(3)$ & $1.301(9)$ \\
$\mathrm{Pt}-\mathrm{C}(2)$ & $1.991(8)$ & $\mathrm{C}(7)-\mathrm{N}(5)$ & $1.36(1)$ \\
$\mathrm{Pt}-\mathrm{C}(7)$ & $2.007(7)$ & $\mathrm{C}(8)-\mathrm{N}(4)$ & $1.29(1)$ \\
$\mathrm{Pt}-\mathrm{C}(8)$ & $2.009(7)$ & $\mathrm{C}(8)-\mathrm{N}(6)$ & $1.367(9)$ \\
$\mathrm{C}(1)-\mathrm{N}(1)$ & $1.16(1)$ & $\mathrm{N}(3)-\mathrm{N}(4)$ & $1.405(8)$ \\
$\mathrm{C}(2)-\mathrm{N}(2)$ & $1.12(1)$ & & \\
$\mathrm{C}(1)-\mathrm{Pt}-\mathrm{C}(2)$ & $90.9(3)$ & $\mathrm{Pt}-\mathrm{C}(7)-\mathrm{N}(3)$ & $113.7(5)$ \\
$\mathrm{C}(1)-\mathrm{Pt}-\mathrm{C}(7)$ & $173.3(3)$ & $\mathrm{Pt}-\mathrm{C}(7)-\mathrm{N}(5)$ & $124.0(6)$ \\
$\mathrm{C}(1)-\mathrm{Pt}-\mathrm{C}(8)$ & $96.3(3)$ & $\mathrm{C}(7)-\mathrm{N}(3)-\mathrm{N}(4)$ & $119.5(6)$ \\
$\mathrm{Pt}-\mathrm{C}(1)-\mathrm{N}(1)$ & $179.2(9)$ & $\mathrm{C}(7)-\mathrm{N}(5)-\mathrm{C}(9)$ & $132.1(7)$ \\
$\mathrm{Pt}-\mathrm{C}(2)-\mathrm{N}(2)$ & $174.9(8)$ & & \\
\hline
\end{tabular}

Table 2

UV-vis spectral data for $\mathbf{1 - 4}$ in acetonitrile at $298 \mathrm{~K}$

\begin{tabular}{ll}
\hline Complex & $\lambda_{\max }(\mathrm{nm})\left(\varepsilon\left(\mathrm{dm}^{3} \mathrm{~mol}^{-1} \mathrm{~cm}^{-1}\right)\right)$ \\
\hline$\left[\left(\mathrm{C}_{10} \mathrm{H}_{21} \mathrm{~N}_{4}\right) \mathrm{Pt}(\mathrm{CN})\right.$ & $234(20300), 282(10100), 326(2700), 390$ \\
$\left.\left(\mathrm{CN}^{t} \mathrm{Bu}\right)\right](\mathbf{1})$ & $(2480)$ \\
{$\left[\left(\mathrm{C}_{10} \mathrm{H}_{21} \mathrm{~N}_{4}\right)\right.$} & $229(17300), 271(10500), 292(\mathrm{sh}, 5400)$, \\
$\left.\mathrm{Pt}\left(\mathrm{CN}^{t} \mathrm{Bu}\right)_{2}\right]^{+}(\mathbf{2})$ & $325(1900), 406(2150)$ \\
{$\left[\left(\mathrm{C}_{10} \mathrm{H}_{22} \mathrm{~N}_{4}\right) \mathrm{Pt}(\mathrm{CN})\right.$} & $234(15300), 282(14100), 298(6700), 311$ \\
$\left.\left(\mathrm{CN}^{t} \mathrm{Bu}\right)\right]^{+}(\mathbf{3})$ & $(5700), 330(2700)$ \\
$\left(\mathrm{C}_{10} \mathrm{H}_{22} \mathrm{~N}_{4}\right)$ & $227(12500), 270(9500), 288(6700), 310$ \\
$\left.\mathrm{Pt}\left(\mathrm{CN}^{t} \mathrm{Bu}\right)_{2}\right]^{2+}(\mathbf{4})$ & $(6800), 330(3750)$ \\
\hline
\end{tabular}

$\left[\left(\mathrm{C}_{10} \mathrm{H}_{22} \mathrm{~N}_{4}\right) \mathrm{Pt}\left(\mathrm{CN}^{t} \mathrm{Bu}\right)_{2}\right]\left(\mathrm{BF}_{4}\right)_{2} \quad\left(4\left(\mathrm{BF}_{4}\right)_{2}\right)$, respectively (Fig. 1). Discernible changes are observed by ${ }^{1} \mathrm{H}-\mathrm{NMR}$ spectroscopy upon protonation. For example, the ${ }^{1} \mathrm{H}-$ NMR spectrum of 1 in $\mathrm{CDCl}_{3}$ shows singlets at 1.37 , 1.41 (inequivalent $\left.{ }^{t} B u \mathrm{NH}\right)$ and $1.59\left(\mathrm{CN}^{t} \mathrm{Bu}\right) \mathrm{ppm}$, and three very broad peaks at $4.17,6.55$ and $8.11(\mathrm{NH})$ ppm. After protonation, the ${ }^{1} \mathrm{H}-\mathrm{NMR}$ spectrum of $3\left(\mathrm{BF}_{4}\right)$ reveals almost equivalent ${ }^{t} \mathrm{Bu} \mathrm{NH}$ singlets at 1.46 and $1.47 \mathrm{ppm}$, while the $\mathrm{CN}^{t} \mathrm{Bu}$ singlet has shifted slightly downfield to $1.66 \mathrm{ppm}$. Significantly, four resonances with broad ${ }^{195} \mathrm{Pt}$ satellites are observed at 5.70,
7.18, 9.92 and $9.99 \mathrm{ppm}$, and these correspond to the amine protons. The fact that the two highly deshielded peaks at 9.92 and 9.99 ppm exhibit comparable intensities and ${ }^{3} J_{\mathrm{PtH}}$ values implies protonation of the nitrogen atom in the heterocyclic bis(carbene) moiety as expected.

The molecular structure of the neutral $\mathrm{Pt}(\mathrm{II})$ complex $\left[\left(\mathrm{C}_{10} \mathrm{H}_{21} \mathrm{~N}_{4}\right) \mathrm{Pt}(\mathrm{CN})\left(\mathrm{CN}^{t} \mathrm{Bu}\right)\right](\mathbf{1})$ has been determined by $\mathrm{X}$-ray crystallography and is shown in Fig. 2; selected bond lengths and angles are listed in Table 1. A distorted square-planar environment around the metal core and a planar $\mathrm{PtC}_{2} \mathrm{~N}_{2}$ metallacycle $[7,16]$ are observed (in the refinement process, half occupancies have been assigned to two hydrogens attached to the two nitrogen atoms because they are crystallographically indistinguishable). The $\mathrm{Pt}-\mathrm{C}($ carbene $)$ distances (2.007(7) and 2.009(7) $\AA$ for $\mathrm{Pt}-\mathrm{C}(7)$ and $\mathrm{Pt}-\mathrm{C}(8)$, respectively) are similar to those in $\left[\mathrm{Pt}(\mathrm{CN})\left(\mathrm{C}_{10} \mathrm{H}_{21} \mathrm{~N}_{4}\right)\right]_{6}$ [7] (1.97(1)-2.01(1) $\AA$ ) and other Pt(II) carbene complexes with or without heteroatom stabilization ([8] and references therein). Such $\mathrm{Pt}-\mathrm{C}$ (carbene) interactions are expected to be predominantly $\sigma$ in nature with minimal $\pi$ character, and the observation of comparable $\mathrm{Pt}-$ $\mathrm{C}$ (cyanide) and $\mathrm{Pt}-\mathrm{C}($ isocyanide) bond lengths (2.006(8) and 1.991(8) $\AA$, respectively) in 1 reinforces this notion. The short $\mathrm{C}(1)-\mathrm{N}(1)$ and $\mathrm{C}(2)-\mathrm{N}(2)$ distances $(1.16(1)$ and $1.12(1) \AA$, respectively) are consistent with carbon-nitrogen triple bonds in the isocyanide and cyanide ligands.

\subsection{Absorption and emission spectroscopy: pH-dependent behavior}

The UV-vis spectrum of $2\left(\mathrm{ClO}_{4}\right)$ in $\mathrm{CH}_{3} \mathrm{CN}$ displays a moderately intense absorption band at $406 \mathrm{~nm}$ $\left(\varepsilon_{\max }=2150 \mathrm{dm}^{3} \mathrm{~mol}^{-1} \mathrm{~cm}^{-1}\right.$, Table 2). This band is solvatochromic in nature [e.g. $384 \mathrm{~nm}\left(\varepsilon_{\max }=2000 \mathrm{dm}^{3}\right.$ $\mathrm{mol}^{-1} \mathrm{~cm}^{-1}$ ) in deionized water] and is tentatively assigned as a charge transfer transition with $\mathrm{Pt} \rightarrow$ $\pi^{*}$ (carbene) MLCT character. This is consistent with the observed blue shift for the methylisocyanide-derived $\mathrm{Pd}$ (II) analog (345 $\mathrm{nm}$ in $\mathrm{CH}_{3} \mathrm{CN}$ ) relative to the $\mathrm{Pt}(\mathrm{II})$ congener $(410 \mathrm{~nm})$ [20]. Assignment to $\mathrm{Pt} \rightarrow \pi^{*}\left(\mathrm{CN}^{-}\right) /$ $\pi^{*}(\mathrm{CNR})$ transitions is not favored, since $\mathrm{Pt}(\mathrm{II})$ cyanide and alkylisocyanide derivatives bearing $\pi$-acid ligands do not absorb strongly at $\lambda>300 \mathrm{~nm}$. For example, the lowest energy absorption band for [Pt(dppe)$(\mathrm{CN})_{2}$ ] (dppe $=1,2$-bis(diphenylphosphino)ethane) and $\left[\mathrm{Pt}\left(\mathrm{CN}^{t} \mathrm{Bu}\right)_{2}(\mathrm{CN})_{2}\right]$ appear at 294 and $282 \mathrm{~nm}$, respectively in methanol [21]. Furthermore, the $\mathrm{Pt} \rightarrow \pi^{*}\left(\mathrm{CN}^{-}\right)$ transition of $\left[\mathrm{Pt}(\mathrm{CN})_{4}\right]^{2-}$ occurs at $280 \mathrm{~nm}$ [22]. The $390 \mathrm{~nm}$ band for $\mathbf{1}$ is similarly ascribed to a MLCTtype transition.

The photophysical responses by $2\left(\mathrm{ClO}_{4}\right)$ as a function of $\mathrm{pH}$ have been examined. The UV-vis spectral behavior of $2\left(\mathrm{ClO}_{4}\right)$ at $\mathrm{pH} 2$ to 11 in deionized water is 
monitored, and a well-defined transformation is detected between $\mathrm{pH} 3$ and 6 . Outside this $\mathrm{pH}$ range, the spectral changes are more complex and a secondary process other than protonation/deprotonation is pre-

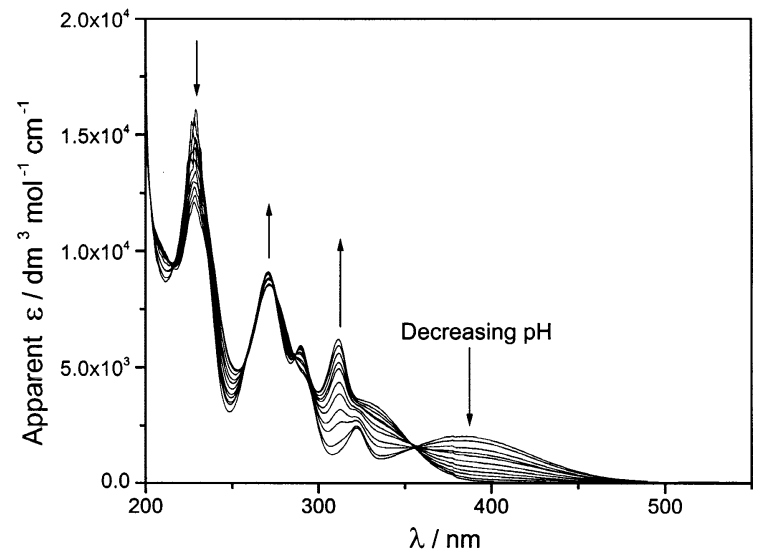

Fig. 3. UV-vis absorption spectral traces for $2\left(\mathrm{ClO}_{4}\right)$ against $\mathrm{pH}$ $(6.08,5.69,5.21,4.98,4.77,4.58,4.42,4.29,4.14,3.89,3.10)$ upon addition of $\mathrm{HBF}_{4}$ in $0.1 \mathrm{M}$ aqueous $\mathrm{NaCl}$ solution at $298 \mathrm{~K}$.

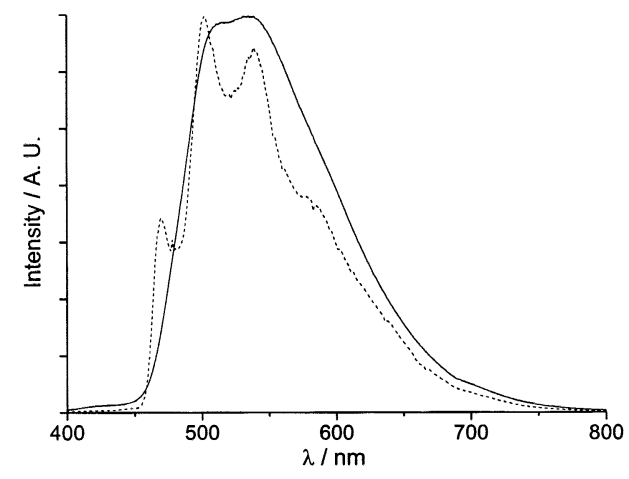

Fig. 4. Normalized solid-state emission spectra of 1 at 298 (-) and $77(--) \mathrm{K}\left(\lambda_{\mathrm{ex}}=350 \mathrm{~nm}\right)$.

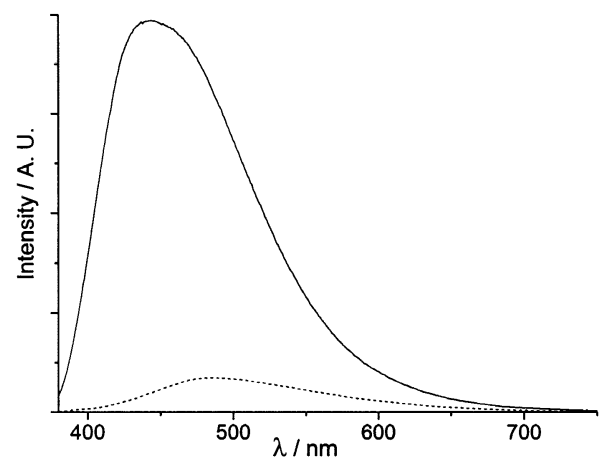

Fig. 5. Emission spectra of 1 in acetonitrile at $298 \mathrm{~K}\left(\lambda_{\mathrm{ex}}=350 \mathrm{~nm}\right)$ before (---) and after (-) addition of excess $\mathrm{HBF}_{4}$. sumably occurring. The UV-vis spectral traces for $2\left(\mathrm{ClO}_{4}\right)$ at $\mathrm{pH} 6.08$ to 3.10 upon addition of $\mathrm{HBF}_{4}$ are shown in Fig. 3. Upon decreasing the $\mathrm{pH}$, the intensity of the absorption band at $\lambda_{\max } 384 \mathrm{~nm}$ decreases while those at $\lambda_{\max } 312$ and 328 (sh) $\mathrm{nm}$ increase. Isosbestic points are evident at 286 and $356 \mathrm{~nm}$ and a color change from yellow to colorless is observed. These spectral changes are reversible as the $384 \mathrm{~nm}$ band is recovered upon addition of hydrazine. The $\mathrm{UV}$-vis spectra of $3\left(\mathrm{BF}_{4}\right)$ and $\mathbf{4}\left(\mathrm{BF}_{4}\right)_{2}$ in acetonitrile (Table 2) both show a moderately intense shoulder at $\lambda_{\max } 330 \mathrm{~nm}\left(\varepsilon_{\max } \sim 3 \times 10^{3} \mathrm{dm}^{3} \mathrm{~mol}^{-1} \mathrm{~cm}^{-1}\right)$. This further demonstrates that protonation of the heterocyclic bis(carbene) moiety produces a blue shift for the lowest energy absorption.

The luminescence of complexes $\mathbf{1}$ and $2\left(\mathrm{ClO}_{4}\right)$ in solution at room temperature is extremely weak, but their solid-state emissions are more pronounced. ${ }^{1}$ Upon excitation at $350 \mathrm{~nm}$, crystalline 1 emits at $\lambda_{\max }$ 508 and $536 \mathrm{~nm}(\tau=0.27 \mu \mathrm{s})$ at $298 \mathrm{~K}$, while a wellresolved vibronic structure $(470,502(\max ), 537,579$ $\mathrm{nm}$ ) is displayed at $77 \mathrm{~K}$ (Fig. 4). The observed vibrational spacing of ca. $1350 \mathrm{~cm}^{-1}$ correlates with the $\mathrm{C}=\mathrm{N}$ stretching of the chelating bis(carbene) moiety, and signifies its involvement in the excited state. We therefore tentatively assign these excited states as ${ }^{3}$ MLCT Pt $\rightarrow \pi^{*}$ (carbene) in nature.

The potential employment of $\mathbf{1}$ and $\mathbf{2}\left(\mathrm{ClO}_{4}\right)$ as luminescent $\mathrm{pH}$ sensors has been investigated. The photoluminescence of complex $\mathbf{1}$ is extremely weak in acetonitrile at $298 \mathrm{~K}\left(\lambda_{\max } \sim 490 \mathrm{~nm}, \phi<5 \times 10^{-4}\right)$. However, emission enhancement (ca. 12-fold) accompanied by a blue shift to $\lambda_{\max } 442 \mathrm{~nm}$ is detected upon addition of excess $\mathrm{HBF}_{4}\left(\lambda_{\text {ex }} 350 \mathrm{~nm}\right.$, Fig. 5). Likewise, $\mathbf{2}\left(\mathrm{ClO}_{4}\right)$ is weakly emissive in acetonitrile $\left(\lambda_{\max }\right.$ $\sim 520 \mathrm{~nm}, \phi<1 \times 10^{-3}$ ), but addition of $\mathrm{HBF}_{4}$ yields an increase in the emission intensity plus a blue shift to $\lambda_{\max } 461 \mathrm{~nm}^{2}{ }^{2}$ Importantly, these responses are reversible upon treatment with hydrazine. The observed high-energy emissions in acidic acetonitrile solutions of $\mathbf{1}$ and $\mathbf{2}\left(\mathrm{ClO}_{4}\right)$ are assigned to the triplet intraligand excited state of the heterocyclic bis(carbene) moiety.

\footnotetext{
${ }^{1}$ This is presumably due to solvent interactions with the coordinatively unsaturated $\mathrm{Pt}$ (II) center in the excited state, like for platinum diimine complexes.

${ }^{2}$ The $298 \mathrm{~K}$ fluid emissions of the protonated derivatives $\mathbf{3}\left(\mathrm{BF}_{4}\right)$ and $\mathbf{4}\left(\mathrm{BF}_{4}\right)_{2}$ in acetonitrile appear at $\lambda_{\max } 430$ and $445 \mathrm{~nm}(\tau \sim 0.3$ $\mu \mathrm{s})$, respectively. As suggested by a reviewer, the discrepancies between these emission maxima and those observed for the in situ protonation of $\mathbf{1}$ and $\mathbf{2}\left(\mathrm{ClO}_{4}\right)$ may be attributed to ion-pairing effects resulting in equilibrating processes in the latter.
} 

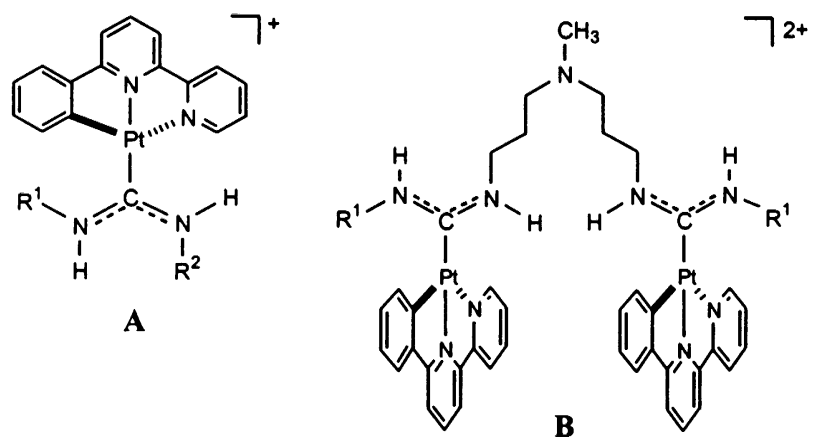

Fig. 6. Luminescent $\mathrm{Pt}(\mathrm{II})$ diamino-carbene complexes.

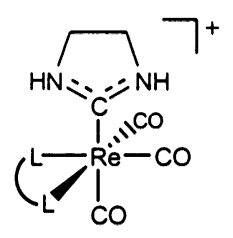

C

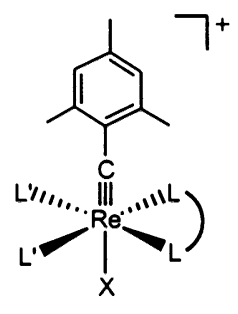

D

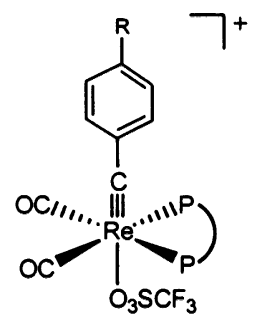

$\mathbf{E}$
Fig. 7. Luminescent $\operatorname{Re}(\mathrm{I})$ carbene and $\operatorname{Re}(\mathrm{V})$ benzylidyne complexes.

\section{Overview}

\subsection{Luminescent Pt(II) chelating bis(carbene) complexes}

The self-assembly of square-planar $\mathrm{Pt}(\mathrm{II})$ building blocks and cyanide bridging modules afforded the novel hexanuclear macrocycle $\left[\mathrm{Pt}(\mathrm{CN})\left(\mathrm{C}_{10} \mathrm{H}_{21} \mathrm{~N}_{4}\right)\right]_{6}(\mathbf{5})$ [7]. The crystal structure of $\mathbf{5}$ revealed an open cubanetype structure with six platinum vertices bridged by six cyanide ligands, thus the molecule is puckered in a chairlike conformation. The emission of 5 at $519 \mathrm{~nm}$ in $\mathrm{CH}_{2} \mathrm{Cl}_{2}$ can be regarded as the first observation of a metal $\rightarrow \pi^{*}$ (carbene) charge transfer excited state in solution at room temperature. The long lifetime and high energy (ca. $2.8 \mathrm{eV}, E_{0-0}$ taken as $450 \mathrm{~nm}$ ) of the excited state imply that this complex can undergo bimolecular photoreactions.

The new work in this account illustrates the pH-dependent photophysical behavior by the mononuclear heterocyclic bis(carbene) platinum(II) complexes 1 and $2\left(\mathrm{ClO}_{4}\right)$. The $\mathrm{UV}$-vis spectrum of $2\left(\mathrm{ClO}_{4}\right)$ shows a blue shift for the lowest energy absorption band from 384 $\mathrm{nm}$ at $\mathrm{pH} 6$ to $312(\mathrm{sh} 328) \mathrm{nm}$ at $\mathrm{pH} 3$. The solid-state emissions of $\mathbf{1}$ and $\mathbf{2}\left(\mathrm{ClO}_{4}\right)$ are assigned as ${ }^{3} \mathrm{MLCT}$ $\mathrm{Pt} \rightarrow \pi^{*}$ (carbene) in nature; we believe that this is the first report of an emissive metal $\rightarrow \pi^{*}$ (carbene) excited state for mononuclear complexes. Luminescence enhancement and blue-shifted emission energies are observed for 1 and $\mathbf{2}\left(\mathrm{ClO}_{4}\right)$ in acidic media. Significantly, these photophysical responses are reversible upon treat- ment with hydrazine. Limitations of this system with respect to $\mathrm{pH}$-sensing applications are clear: secondary reactions/processes are apparently taking place under highly acidic and basic conditions, while the degree of emission enhancement is noticeable yet not dramatic. Nevertheless, the intention of this report is to introduce Fischer-type carbene complexes as potential luminescent chemosensors.

\subsection{Luminescent Pt(II) diamino-carbene complexes [8]}

A series of luminescent diimine-supported platinu$\mathrm{m}(\mathrm{II})$ diamino-carbene complexes, namely [(CNN)$\left.\mathrm{Pt}\left\{\mathrm{C}\left(\mathrm{NHR}^{1}\right)\left(\mathrm{NHR}^{2}\right)\right\}\right]^{+} \quad(\mathbf{A}, \quad \mathrm{HCNN}=6$-phenyl-2, 2'bipyridine; for $\mathrm{R}^{1}={ }^{t} \mathrm{Bu}, 2,6-\mathrm{Me}_{2} \mathrm{C}_{6} \mathrm{H}_{3} ; \mathrm{R}^{2}=\mathrm{Me}, \mathrm{NH}_{2}$, $\mathrm{CH}_{2} \mathrm{Ph}$ ), have been synthesized by nucleophilic attack of amines at the coordinated isocyanide ligands of $\left[(\mathrm{CNN}) \mathrm{PtC} \equiv \mathrm{NR}^{1}\right]^{+}$. The binuclear bridging bis(carbene) derivative $\left[\{(\mathrm{CNN}) \mathrm{Pt}\}_{2}-\mu-\left\{\mathrm{C}\left(\mathrm{NH}^{t} \mathrm{Bu}\right)(\mathrm{NH}-\right.\right.$ $\left.\left.\left.\left(\mathrm{CH}_{2}\right)_{3}\right)\right\}_{2} \mathrm{NMe}\right]^{2+}($ B) was also prepared (Fig. 6). All compounds display structureless emissions in acetonitrile at room temperature $\left(\lambda_{\max } 528-558 \mathrm{~nm}\right)$ and these are assigned to ${ }^{3} \mathrm{MLCT}$ excited states. The isocyanide derivatives emit with substantially higher quantum yields (ca. 0.1 ), while low energy bands $\left(\lambda_{\max }>600 \mathrm{~nm}\right)$ assigned to $\pi-\pi$ excimeric or metal-metal-to-ligand charge transfer $\left({ }^{3} \mathrm{MMLCT}\right)$ excited states have been observed in concentrated glassy solutions.

\subsection{Luminescent $\operatorname{Re}(I) \mathrm{N}$-heterocyclic carbene complexes [9]}

Rhenium(I) $N$-heterocyclic carbene complexes of the type $\left[\mathrm{HNCH}_{2} \mathrm{CH}_{2} \mathrm{NHCRe}(\mathrm{L}-\mathrm{L})(\mathrm{CO})_{3}\right]^{+}(\mathbf{C}$, Fig. 7) have been prepared [L-L $=4,4^{\prime}$-dimethoxy-2,2' bipyridine, 4,4'-bis( $t$-butyl)-2,2'-bipyridine, 2,2'-bipyridine, 4,4'-dichloro-2,2'-bipyridine, 4,4'-bis(carbomethoxy)-2,2'-bipyridine, 5-phenyl-1,10-phenanthroline, $o$ phenylenebis(diphenylphosphine)]. All diimine derivatives are emissive in fluid solution at $298 \mathrm{~K}$ and in frozen glasses at $77 \mathrm{~K}$. The combination of detailed spectroscopic studies and theoretical calculations suggested that the emitting state at room temperature is ${ }^{3}$ MLCT in nature; namely ${ }^{3}\left[\mathrm{~d}(\mathrm{Re}) \rightarrow \pi^{*}\right.$ (diimine) $]$ with the latter exhibiting partial $\pi^{*}$ (carbene) parentage. Subtle modification of the excited state energies (e.g. $\lambda_{\max }$ $565-635 \mathrm{~nm}$ in acetonitrile) and redox potentials have been demonstrated using diimine auxiliaries with different electron-donating/accepting abilities.

\subsection{Luminescent $\operatorname{Re}(V)$ and -(VI) benzylidyne complexes}

Efficient methodologies for the synthesis of two series of luminescent rhenium(V) benzylidyne complexes, 
namely (i) 2,4,6-trimethylbenzylidyne species bearing various phosphorus or nitrogen donor ligands (D), and (ii) para-substituted benzylidyne derivatives supported by $o$-phenylenebis(diphenylphosphine) (E, Fig. 7), have been developed $[10,11]$. The rhenium(V) benzylidyne complexes display photoluminescence at room temperature and $77 \mathrm{~K}$. Data from electronic absorption and emission spectra, electrochemistry, and molecular orbital calculations provided evidence to suggest that the excited state for diimine-supported species is $\mathrm{d}(\mathrm{Re}) \rightarrow$ $\pi^{*}\left(\mathrm{X}_{2}\right.$-bpy $)$. In contrast, the emitting state for the remaining derivatives were assigned as ${ }^{3}\left[\pi(\mathrm{Re} \equiv \mathrm{CAr}) \rightarrow \pi^{*}(\mathrm{Re} \equiv \mathrm{CAr})\right] \quad$ with $\quad \mathrm{d}(\mathrm{Re}) \rightarrow \pi^{*}(\equiv \mathrm{CAr})$ MLCT character. Significantly, the excited-state properties associated with this class of chromophores have been modified with different benzylidyne and ancillary ligands. Hence the emission energy can be tuned from 520 to $610 \mathrm{~nm}$ in $\mathrm{CH}_{2} \mathrm{Cl}_{2}$; a range of $2840 \mathrm{~cm}^{-1}$. The excited state lifetimes can be adjusted from 20 ns to $4.84 \mu \mathrm{s}$, many of which are noticeably longer than those observed in related Mo, W and Os alkylidyne/carbyne systems [13-15].

The first examples of emissive $\mathrm{d}^{1}$ complexes containing a metal-carbon multiple bond, namely $\mathrm{Re}^{\mathrm{VI}}\left(\equiv \mathrm{CAr}^{\prime}\right)\left(\mathrm{PPh}_{3}\right)\left(\mathrm{H}_{2} \mathrm{O}\right) \mathrm{X}_{3} \quad\left(\mathrm{X}=\mathrm{Cl}\right.$ and $\mathrm{Br}, \quad \mathrm{Ar}^{\prime}=$ 2,4,6- $\left.\mathrm{Me}_{3} \mathrm{C}_{6} \mathrm{H}_{2}\right)$, were prepared from $\left[\mathrm{Re}^{\mathrm{V}}\left(\equiv \mathrm{CAr}^{\prime}\right)\left(\mathrm{PPh}_{3}\right)_{2}(\mathrm{CO})\left(\mathrm{H}_{2} \mathrm{O}\right) \mathrm{Cl}\right] \mathrm{ClO}_{4}$ by treatment with $\mathrm{HCl}$ in chloroform and by photooxidation in dibromomethane respectively [12]. The crystal structure for $\mathrm{X}=\mathrm{Cl}$ revealed a $\mathrm{Re}=\mathrm{C}$ distance of $1.738(6) \AA$. Excitation of the $\operatorname{Re}(\mathrm{VI})$ benzylidyne species at $\lambda>300$ $\mathrm{nm}$ in $\mathrm{CH}_{2} \mathrm{Cl}_{2}$ produced red emission $\left(\lambda_{\max } 696\right.$ and 728 $\mathrm{nm}$ for $\mathrm{X}=\mathrm{Cl}$ and $\mathrm{Br}$, respectively) with lifetimes of ca. $0.4 \mu \mathrm{s}$.

\section{Supplementary material}

Crystallographic data for the structures reported in this paper have been deposited with the Cambridge Crystallographic Data Centre, CCDC no. 150179 for complex 1. Copies of this information may be obtained free of charge from the Director, CCDC, 12 Union Road, Cambridge, CB2 1EZ, UK (fax: + 44-1223336033; e-mail: deposit@ccdc.cam.ac.uk or http:// www.ccdc.cam.ac.uk).

\section{Acknowledgements}

We are grateful for financial support from The University of Hong Kong and the Research Grants Council of the Hong Kong SAR, China [HKU 7298/99P]. We thank the reviewers for helpful comments and suggestions.

\section{References}

[1] G. Wilkinson, F.G.A. Stone, E.W. Abel ((Eds.), Comprehensive Organometallic Chemistry II, Pergamon, New York, 1995.

[2] (a) J.R. Winkler, H.B. Gray, Inorg. Chem. 24 (1985) 346. (b) H.H. Thorp, J.V. Houten, H.B. Gray, Inorg. Chem. 28 (1989) 889. (c) G.A. Neyhart, M. Bakir, J. Boaz, W.J. Vining, B.P. Sullivan, Coord. Chem. Rev. 111 (1991) 27. (d) J.G. Goll, W. Liu, H.H. Thorp, J. Am. Chem. Soc. 115 (1993) 11048.

[3] (a) C.M. Che, T.C. Lau, H.W. Lam, C.K. Poon, J. Chem. Soc. Chem. Commun. (1989) 114. (b) C.M. Che, H.W. Lam, T.C.W. Mak, J. Chem. Soc. Chem. Commun. (1989) 1529. (c) V.W.W. Yam, C.M. Che, Coord. Chem. Rev. 97 (1990) 93.

[4] (a) E.O. Fischer, H. Fischer, Chem. Ber. 107 (1974) 657. (b) R.M. Dahlgren, J.I. Zink, Inorg. Chem. 16 (1977) 3154. (c) C.P. Casey, A.J. Shusterman, N.W. Vollendorf, K.J. Haller, J. Am. Chem. Soc. 104 (1982) 2417. (d) H.C. Foley, L.M. Strubinger, T.S. Targos, G.L. Geoffroy, J. Am. Chem. Soc. 105 (1983) 3064. (e) S.E.J. Bell, K.C. Gordon, J.J. McGarvey, J. Am. Chem. Soc. 110 (1988) 3107. (f) A.D. Rooney, J.J. McGarvey, K.C. Gordon, Organometallics 14 (1995) 107

[5] L.S. Hegedus, Acc. Chem. Res. 28 (1995) 299.

[6] V.W.W. Yam, B.W.K. Chu, K.K. Cheung, Chem. Commun. (1998) 2261.

[7] S.W. Lai, K.K. Cheung, M.C.W. Chan, C.M. Che, Angew. Chem. Int. Ed. 37 (1998) 182.

[8] S.W. Lai, M.C.W. Chan, K.K. Cheung, C.M. Che, Organometallics 18 (1999) 3327.

[9] W.M. Xue, M.C.W. Chan, Z.M. Su, K.K. Cheung, S.T. Liu, C.M. Che, Organometallics 17 (1998) 1622.

[10] W.M. Xue, Y. Wang, T.C.W. Mak, C.M. Che, J. Chem. Soc. Dalton Trans. (1996) 2827.

[11] W.M. Xue, Y. Wang, M.C.W. Chan, Z.M. Su, K.K. Cheung, C.M. Che, Organometallics 17 (1998) 1946.

[12] W.M. Xue, M.C.W. Chan, T.C.W. Mak, C.M. Che, Inorg. Chem. 36 (1997) 6437.

[13] A.B. Bocarsly, R.E. Cameron, H.D. Rubin, G.A. McDermott, C.R. Wolff, A. Mayr, Inorg. Chem. 24 (1985) 3976.

[14] (a) J.D. Carter, K.B. Kingsburg, A. Wilde, T.K. Schoch, C.J. Leep, E.K. Pham, L. McElwee-White, J. Am. Chem. Soc. 113 (1991) 2947. (b) J. Manna, T.M. Gilbert, R.F. Dallinger, S.J. Geib, M.D. Hopkins, J. Am. Chem. Soc. 114 (1992) 5870. (c) S. Trammell, B.P. Sullivan, L.M. Hodges, W.D. Harman, S.R. Smith, H.H. Thorp, Inorg. Chem. 34 (1995) 2791. (d) T.K. Schoch, A.D. Main, R.D. Burton, L.A. Lucia, E.A. Robinson, K.S. Schanze, L. McElwee-White, Inorg. Chem. 35 (1996) 7769.

[15] Group 6 carbyne derivatives: (a) F.W. Lee, M.C.W. Chan, K.K. Cheung, C.M. Che, J. Organomet. Chem. 552 (1998) 255. (b) F.W. Lee, M.C.W. Chan, K.K. Cheung, C.M. Che, J. Organomet. Chem. 563 (1998) 191.

[16] (a) L. Chugaev, M. Skanavy-Grigorieva, A. Posniak, Z. Anorg. Allg. Chem. 148 (1925) 37. (b) G. Rouschias, B.L. Shaw, J. Chem. Soc. A (1971) 2097. (c) W.M. Butler, J.H. Enemark, J. Parks, A.L. Balch, Inorg. Chem. 12 (1973) 451.

[17] (a) J.K. Barton, S.J. Lippard, Biochemistry 18 (1979) 2661. (b) J.C. Dewan, S.J. Lippard, W.R. Bauer, J. Am. Chem. Soc. 102 (1980) 858. (c) W.D. McFadyen, L.P.G. Wakelin, I.A.G. Roos, B.L. Hillcoat, Biochem. J. 242 (1987) 177. (d) H.Q. Liu, S.M. Peng, C.M. Che, J. Chem. Soc. Chem. Commun. (1995) 509. (e) C.S. Peyratout, T.K. Aldridge, D.K. Crites, D.R. McMillin, Inorg. Chem. 34 (1995) 4484. (f) L. Monsú Scolaro, R. Romeo, A. Terracina, Chem. Commun. (1997) 1451. (g) Y. Kunugi, K.R. Mann, L.L. Miller, C.L. Exstrom, J. Am. Chem. Soc. 120 (1998) 589. (h) K.H. Wong, M.C.W. Chan, C.M. Che, Chem. Eur. J. 5 (1999) 2845. 
[18] (a) S.P. Kaiwar, A. Vodacek, N.V. Blough, R.S. Pilato, J. Am. Chem. Soc. 119 (1997) 3311. (b) S.P. Kaiwar, A. Vodacek, N.V. Blough, R.S. Pilato, J. Am. Chem. Soc. 119 (1997) 9211.

[19] G.M. Sheldrick, SHELXTL Version 5.03, Siemens Analytical X-ray Instruments Inc, Madison, WI, USA, 1994.
[20] A.L. Balch, J.E. Parks, J. Am. Chem. Soc. 96 (1974) 4114.

[21] S.W. Lai, C.M. Che, unpublished results.

[22] J.W. Schindler, R.C. Fukuda, A.W. Adamson, J. Am. Chem. Soc. 104 (1982) 3596. 